\title{
Attitude Towards Science Among Lower Secondary Students in Johor Bahru
}

\author{
${ }^{1}$ Leong Sok Yee \& ${ }^{2}$ Yazid Abdul Manap \\ ${ }^{1}$ Open University Malaysia, Kuala Lumpur, Malaysia \\ ${ }^{2}$ Institut Pendidikan Guru Kampus Temenggong Ibrahim, Johor Bahru, Johor, Malaysia \\ Corresponding author : leong80gina@yahoo.com, ${ }^{2}$ yazifik@gmail.com
}

\begin{abstract}
The purpose of the study was to investigate attitude towards science among lower secondary students in Johor Bahru. The attitude in this study included interest, perception towards science and motivation. The study was carried out in Johor Bahru, Johor. The study adopted quantitative descriptive research designs and questionnaires were used in the study. A total of 370 respondents constituted the sample of the study, which included Form 2 lower secondary students from Johor Bahru. Data was analysed to obtain frequency, mean and standard deviation. The results revealed that laboratory activity, curiosity to discovery science and science as a tool to understand the world is able to improve science learning. As a conclusion, interest especially created by laboratory activity, perception of student when they are curios to discovery science and motivation factor when students know that science as a tool to understand the world are able to improve students science learning in lower secondary schools in Johor Bahru. The implication was that school teachers could prepare more laboratory activities in science lesson. They also can stimulate students' curiosity to discovery science and related science knowledge to the world so that students are interested and motivated to learn science. Future studies on this subject would be beneficial to understand more deeply the relationship between student personal factors with science achievement.
\end{abstract}

Keywords: Attitude, interest, perception, motivation, science learning

\begin{abstract}
Abstrak
Tujuan kajian ini adalah mengkaji sikap pelajar sekolah menengah rendah terhadap sains di Johor Bahru. Sikap dalam kajian ini merangkumi minat, persepsi terhadap sains dan motivasi. Kajian ini dijalankan di Johor Bahru, Johor. Kajian ini menggunakan kaedah kajian kuantitatif deskriptif dan soal selidik digunakan dalam kajian ini. Seramai 370 murid daripada pelajar Tingkatan 2 sekolah menengah rendah Johor Bahru sebagai sampel kajian. Data diproses untuk mendapatkan kekerapan, min dan sisihan piawai. Dapatan kajian menunjukkan aktiviti makmal, keinginan terhadap penemuan sains dan sains sebagai alat untuk memahami dunia dapat meningkatkan pembelajaran sains. Kesimpulannya, peningkatan minat terutama melalui aktiviti makmal, persepsi pelajar apabila mereka mempunyai keinginan kepada penemuan sains dan faktor motivasi apabila pelajar tahu tentang sains sebagai alat untuk memahami dunia boleh meningkatkan pembelajaran sains pelajar di sekolah menengah rendah di Johor Bahru. Implikasinya ialah guru sekolah boleh menyediakan lebih banyak aktiviti makmal dalam pembelajaran sains. Mereka juga boleh merangsang keinginan pelajar terhadap penemuan sains dan pengetahuan sains yang berkaitan dengan dunia supaya para pelajar menjadi minat dan bermotivasi untuk belajar sains. Kajian masa depan dalam subjek ini perlulah dikaji lebih mendalam tentang hubungan antara faktor peribadi pelajar dengan pencapaian sains.
\end{abstract}

Kata kunci: Sikap, minat, persepsi, motivasi, pembelajaran sains 


\section{INTRODUCTION}

Towards the $21^{\text {st }}$ century, science plays an important role in our modern technology society. Our daily life now cannot be separate from science. Therefore, the Ministry of Education (MOE) Malaysia has launched a mission to ensure that the student ratio in Malaysia will be 60:40 - to represent 60\% science stream and $40 \%$ arts stream students in the upper secondary school, since the year 1994 [1]. This effort is important to encourage students to join in engineering, ICT, medical, health science and other science related works. Furthermore, MOE Malaysia made change in the science curriculum recently by emphasizing Higher Order Thinking Skills (HOTS) in science subject. Mullis [2] stated that Malaysia curriculum is designed to help students develop cognitively and emotionally, while providing a platform for developing HOTS and producing well-rounded individuals. Although the effort had been done, it is found that especially after conversion from Lower Secondary Assessment (PMR) to Form 3 Assessment (PT3), the number of students entered into science stream is still far behind the target in Malaysia. Boo [3] stated that when the public examination in Malaysia changed from PMR to PT3 since 2014, the performance of science and mathematics are low. Less than 13 per cent of those who sat for the Form 3 PT3 examination on 2014 scored at least $\mathrm{C}$ in both science and mathematics. The low rate of science achievement is alarming. Thus, the effectiveness of science education can only be improved if we understand the attitude of students towards science.

Students are the end product of education. A teacher is only a person that engages students by helping to organize and assist them as they take the initiative in their own self-directed explorations, instead of directing their learning autocratically [4]. Therefore, most of the literature, attitude or so called interest, perception and motivation towards the science subject had been identified as the factors that affected science learning [5]; [6]; [7]; [8]. Interest is considered important in the learning process because it creates enjoyment and attention towards science learning. Hidi [9] defined interest as a psychological state that, in later phases of development, is also a predisposition to re-engage content that applies to in-school and out-of-school learning and to young and old alike. This means that interest of the students is able to bring up and continue to the older stage and it had given a great impact to the students' learning. According to Elster [10], if the learner is interested in science, then she/he creates a relationship with the object of study. Many researchers believe that interest is able to connect students with the subject. For example, Hulleman [11] found that interest in science had increased course grades for 262 USA high school students through a randomized field experiment design. This research also showed how the motivational principles could be used to increase interest and performance in science. Besides, Mekonnen [7], who examined the problems that challenged academic performance of physics student found that lack of interest in the physics subject, influenced academic performance.

On the other hand, when students perceive that science is difficult to understand they will not able to receive the knowledge easily. Perception is understood as recognition and interpretation of sensory information by students. Wolter [12] stated that the perception of science as boring is a major issue for teachers at all instructional levels. Many studies, such as Phanga [13], discovered that low performance students usually perceive science to be a difficult subject. He had mentioned in their metaanalysis study that students perceived that curriculum of science is difficult and they were unable to understand the science concept related to teaching methodology applied in the classroom. On the other side, Portnov-Neeman [14] in their study which explored students' perceptions about learning in school had found that the students understood and appreciate the importance of learning for their future and were ready to invest efforts in succeeding in school. 
In line with interest, motivation will give a great impart to students' learning. Brophy [15] defined motivation as a theoretical concept that is used to explain the beginning, direction, force and insistence of goal-oriented behaviour. Learning science requires high motivation because it involves cognitive and critical thinking as well as science process skills such as inference, prediction, observation, etc. Students need to take the initiative in acquiring knowledge. Cavas [6] discovered that students' motivational level was found to have a considerable impact on their science attitudes and achievement in science. In general, literatures [16]; [8] showed that students' attitude will affect science learning. Owoeye [16] found a significant relationship in the students' attitude to Biology and students' academic performance in Biology, and the findings also revealed that there was significant relationship in the students' interest in Biology and students' academic performance in Biology in Ekiti State, Nigeria. Furthermore, $\mathrm{Ng}$ [8] who had explored the relationship between positive effect towards science and mathematics and achievement in science and mathematics among Malaysian and Singaporean Grade 8 students when they took the data from TIMSS (2007) included 4,466 Malaysia students and 4,599 Singaporean students. They found a positive effect (attitude) towards science and mathematics indicated statistically significant predictive effects on achievement in the two subjects for both Malaysian and Singaporean Grade 8 students.

The objective of this study is to investigate attitude including interest, perception and motivation towards science among lower secondary students in Johor Bahru. Following research questions were formulated for the study:

1. How students' science learning related to interest?

2. How students' science learning related to students' perception towards science?

3. How students' science learning related to students' motivation?

\section{METHODOLOGY}

The research design used in the study was a quantitative descriptive. The target population in this study are Form 2 students who will sit for their PT3 examinations in October 2018. Johor Bahru consists of 41 secondary schools [17]. Students were randomly selected from these government secondary schools in the Johor Bahru district. Estimated population of Form 2 students in Johor Bahru is 9336 (male = 4698; female $=4638$ ). Therefore, sample size of the study chosen was 370, based on Krejcie [18]. It consisted of 209 males and 161 females.

The study used a questionnaire containing two sections. The first section of the questionnaire was designed to obtain the demographic profiles of students, such as gender, parents' educational level and socioeconomic background. The second section contained a questionnaire divided into 3 constructs to investigate interest, perception and motivation with each construct consisting of 5 questions. The items measured on a 5-point Likert type scale ranging from five for 'strongly agree', four for 'agree', three for 'less disagree' and two for 'disagree' to one for 'strongly disagree'. The questionnaire was developed based on the requirements for each element of the variable intended to answer the research questions. The questionnaire of student factors was adapted from science motivation questionnaire II [19] while the rest of the part of questionnaire was developed by researchers. Questionnaires were distributed to the respondents. All data collected were treated confidentially. Data was analysed using Statistical Package for Social Sciences (SPSS) software to obtain results in terms of mean, frequency and standard deviation. The instrument used had been consulted to two experts in science education 
field from the Institute Pendidikan Guru Temenggong Ibrahim, Johor Bahru Campus to ascertain content validity. They had advised to rearrange the questionnaire based on the three main categories, namely interest, perception and motivation. Researchers had also restructured the sentences of questionnaire and added Malay translation in the questionnaire. This enabled to develop instruments that yield content valid information. A pilot study was conducted by distributing the questionnaires to 35 Form 2 students from the neighbouring Johor Bahru district target population which was intended to determine the reliability of the questionnaire. Result of reliability coefficient in this pilot test showed $0.851(>0.8$, good) which was considered high enough for the instruments to be used for the study.

\section{RESULT AND DISCUSSION}

The questionnaire for students was administered to 450 students and covered secondary schools in Johor Bahru. Out of the number of questionnaires issued, 370 were returned representing $82.2 \%$ which formed the basis of the analysis. A missing values analysis was conducted, and count data was derived for each variable in the study. Two participants had one different item missing each. It was subsequently dropped the numbers of sample from the study, which changed the $\mathrm{N}$ from 370 to 369.

Table 1. Range determine of agreement level

\begin{tabular}{lll}
\hline & Range & Level \\
\hline 1.00 to 1.80 & & Strongly disagree \\
1.81 to 2.60 & Disagree & \\
2.61 to 3.40 & Less disagree & \\
3.41 to 4.20 & Agree & Strongly agree \\
4.21 to 5.00 & & . \\
\hline
\end{tabular}

Based on 5-point Likert type scale, respondents were provided with a series of questions, for which they select 'strongly agree, agree, less disagree, disagree or strongly disagree' (Table 1).

Table 2. Descriptive statistics on how students' science learning relate to interest

\begin{tabular}{lllll}
\hline & Mean & $\mathrm{N}$ & Std. Deviation & Ranking \\
\hline Q16. Learning science is interesting. & 3.63 & 369 & 1.30 & 3 \\
Q17. I like to do science laboratory activities. & 3.88 & 369 & 1.25 & 1 \\
Q18. The science I learn is relevant to my daily & 3.64 & 369 & 1.27 & 2 \\
life. & & & & \\
Q19. I enjoy learning science. & 3.61 & 369 & 1.33 & 4 \\
Q20. I spend a lot of time learning science. & 3.09 & 369 & 1.27 & 5 \\
\hline
\end{tabular}

Although all items values of mean in Table 2 show 'less disagree' which in the range of ' 3 '. Yet, each item does shows a difference in the mean value. Science laboratory activities achieved the highest mean ( $\mu=3.88$ ) which is nearest to ' 4 ' indicating that respondents agree that science laboratory activities are able to improve students' science learning. The mean value of 3.64 showed that science learning will be improved if students think that science is relevant to their daily life. The lowest mean value of 3.09 as nearest to ' 3 ' showed that respondents are 'less disagree' that they spend a lot of time on learning science.

Since the respondents agree that science laboratory activities are able to improve students' science learning, hence it showed that science lab activity is able to promote the interest of students in learning science. Lab activity is a type of inquiry based learning and it has been proven that it is able to motivate students to learn science. In the research done by Maxwell [20], students who received inquiry 
based learning instruction showed a slight statistically insignificant decrease in their positive attitudes towards science but higher engagement as compared to students who received traditional instruction. Therefore, the highest interest of students in science means they will more engage in the subject as Osborne [21] mentioned that students' interest, motivation and attitudes towards school science are important for their engagement in science learning and this become positive effects on the quantity and quality of learning outcomes. Interest is just like pushing force that encouraged students to learn what they like. As a result, students will take initiative in learning. Schiefele [22], using both experimental and correlation designs, has shown that college students' personal interest is positively related to the use of deeper cognitive processing strategies such as elaboration, seeking information, and engagement in critical thinking. With these learning skills, students' performance in the subject is able to improve obviously. Sorić [23], examined the relationship between students' interests, their use of certain specific learning strategies and causal attributions which they made for their academic achievement also confirmed that the learning strategies could be a potential mediator in the relationship between students' interests and their academic achievement. They explained the reason of interest that had influenced the students' result in learning. These findings confirmed the role of interest in the process of learning.

Table 3. Descriptive statistic on how students' science learning is related to perception

\begin{tabular}{lcccc}
\hline & Mean & $\mathrm{N}$ & Std. Deviation & Ranking \\
\hline Q21. I put enough effort into learning science. & 3.42 & 369 & 1.27 & 3 \\
Q22. I believe I can master science knowledge. & 3.35 & 369 & 1.29 & 5 \\
Q23. I am curious about discoveries in science. & 3.67 & 369 & 1.30 & 1 \\
Q24. I prepare well for science tests. & 3.51 & 369 & 1.28 & 2 \\
Q25. I use strategies to learn science well (such as & 3.40 & 369 & 1.42 & 4 \\
attend tuition class, memories facts, do extra & & & & \\
exercise, etc.) & & & \\
\hline
\end{tabular}

The mean value for all items in Table 3 is in the range of ' 3 ' which denote 'less disagree' in the questionnaire. However, the highest mean $(\mu=3.67)$ and second place of mean $(\mu=3.51)$ which are nearest to ' 4 ' as respondents are agree that indicates curiosity about discoveries in science and well prepared science test is closely related to science learning. The lowest mean value, 3.35 which are nearest to ' 3 ' showed that students less disagrees they can master science knowledge.

Curiosity had prepared students' to drill the science knowledge by themselves. This was mentioned by Aikenhead [24], personal curiosity science can be a driving motivational factor in science classrooms. Many of the researchers had substantiated the study findings. Obomanu [25], in their research to investigate factors related to under achievement in Science, Technology and Mathematics Education (STEM) in secondary schools in Rivers State, Nigeria found similar findings that students' develop positive attitude and performance of students abound to enhance in the particular subjects. They also related students' attitude was influenced by teaching activity.

Table 4. Descriptive statistic on how students' science learning is related to motivation

\begin{tabular}{lllll}
\hline & Mean & N & Std. Deviation & Ranking \\
\hline Q26. Learning science will help me to get a good job. & 3.57 & 369 & 1.344 & 4 \\
Q27. I will use science problem solving skills in my & 3.49 & 369 & 1.274 & 5 \\
career. & & & & \\
Q28. Most of the science ideas is useful for me. & 3.63 & 369 & 1.225 & 2 \\
Q29. Learning science makes my life more meaningful. & 3.59 & 369 & 1.261 & 3 \\
Q30. Science can let me understand more about the & 3.90 & 369 & 1.294 & 1 \\
world. & & & & \\
\hline
\end{tabular}


Although all items' values of mean in Table 4 shows 'less disagree' which is in the range of ' 3 '. Each item does shows a difference in the mean value and after rounding off the mean value, they show ' 4 ' as agree to the items. The highest mean $(\mu=3.90)$ indicates that believing about science can let students understand more about the world is able to motivate students in learning science. Usefulness of science ideas is also able to motivate students to learn science. However, the lowest mean value, 3.49 shows that using science problem solving skills in careers has less effect on students' science learning.

Motivation discussed in this study referred to the career or goal oriented and the usefulness of science to the students which become the driving force for students to learn science. Miller [26] argued that it is the students' perceptions of task instrumentality that transmit the value of their future goals and sub-goals to the proximal tasks they are faced with Miller [27]. Therefore, every student should develop their own goal either in present or future, consequently students have a profound impact and performance well in their study. If students see the usefulness of science, positive attitude towards science will be created. This finding is in line with the finding of Harackiewicz [28]. They mentioned that utility-value interventions promoted interest and performance for high-school students in science classes. The results of Vansteenkiste [29], who examined the impact of goal content on a new set of dependent variables, namely, students' levels of experienced stress during their task engagement as well as their goal orientations also pointed out that in addition to the mere fact that an activity is perceived as useful, it seems to be important to consider what it is useful for.

\section{CONCLUSION}

The conclusions were that interest especially created by laboratory activity, perception of student when they are curios to discovery science and motivation factor when students know that science as a tool to understand the world are able to improve students' science learning in lower secondary schools in Johor Bahru. The implication is that school teachers could prepare more laboratory activities in science lessons. They also can stimulate students' curiosity to discovery science and related science knowledge to the world so that students are be interested and motivated to learn science. Future studies on this subject would be beneficial to understand more deeply the relationship between student personal factors with science achievement. Moreover, it would be more interesting to include both form 1 and 3 of lower secondary schools in Johor state or even for the whole country for future research on this subject.

\section{AKNOWLEDGEMENT}

The authors would like to express their gratitude to Pejabat Pendidikan Daerah Johor Bahru and Ministry of Education Malaysia (MOE) for their technical support and permission to carry out the study in government secondary schools.

\section{REFERENCES}

[1] Mok, S. S. (2008). Ilmu pendidikan untuk KPLI (Sek. rendah: Komponen 1 \& 2). Psikologi Pendidikan \& Pedagogi. Subang Jaya: Kumpulan Budiman Sdn. Bhd.

[2] Mullis, I. V. S., Martin, M. O., Goh, S. \& Cotter, K. (Eds.) (2016). TIMSS 2015 Encyclopedia: Education policy and curriculum in mathematics and science. Boston College, TIMSS \& PIRLS International Study Center website. Retrieved from http://timssandpirls.bc.edu/timss2015/encyclopedia/

[3] Boo, S. L. (2015, November 2). Parents partly to blame for bad science results, teachers say. Malaymail online. Retrieved from http://www.themalaymailonline.com/malaysia/article/parents-partly-to-blamefor-bad-science-results-teachers-say 
[4] Strommen, E., F., \& Lincoln, B. (1992). Constructivism, technology, and the future of classroom learning. Children's Television Workshop.

[5] Badlishah, M. N., Mustamam, M. \& Nurulhuda, A. R. (2016). Sikap pelajar terhadap pembelajaran fizik dan hubungan dengan pencapaian dalam kalangan pelajar sains. Jurnal Personalia Pelajar, 19, 23 - 38.

[6] Cavas, P. (2011). Factors affecting the motivation of Turkish primary students for science learning. Science Education International, 22(1), 31 - 42.

[7] Mekonnen, S. (2014). Problems challenging the academic performance of physics students in higher government institutions in the case of Arbaminch, Wolayita Soclo, Hawassa and Dilla Universities. Natural Science, 6, 362 - 375.

[8] Ng, K. T., Lay, Y. F., Areepattamannil, S., Treagust, D. F., \& Chandrasegaran, A. L. (2012). Relationship between affect and achievement in science and mathematics in Malaysia and Singapore. Research in Science \& Technological Education, 30(3), 225-237.

[9] Hidi, S., \& Renninger, K. A. (2006). The four-phase model of interest development. Educational Psychologist, 41(2), 111-127.

[10] Elster, D. (2007). Student interests - the German and Austrian ROSE survey. Educational Research, 42(1), 5 - 11.

[11] Hulleman, C. S. \& Harackiewicz, J. M. (2009). Promoting interest and performance in high school science classes. Science, 326, $1410-1412$.

[12] Wolter, B. H., Lundeberg, M. A. \& Bergland, M. (2013). What makes science relevant? Student perceptions of multimedia case learning in ecology and health. Journal of STEM Education, 14(1), 26 - 35.

[13] Phanga, F. A., Abua, M. S., Alia, M. B., \& Sallehb, S. (2014). Faktor penyumbang kepada kemerosotan penyertaan pelajar dalam aliran sains: Satu analisis sorotan tesis. Sains Humanika, 2(4), 63-71.

[14] Portnov-Neeman, Y., \& Barak, M. (2013). Exploring students' perceptions about learning in school: An activity theory based study. Journal of Education and Learning, 2(3), 9-25.

[15] Brophy, J. E. (2004). Motivating Students to Learn (2nd ed.). Retrieved from http://books.google.com.tr/books?id=gD7_VSNmu7cC\&dq=isbn:0805847723/

[16] Owoeye, P. O., \& Aghaje, R. O. (2016). Students' attitude and gender as correlates of students' academic performance in Biology in senior secondary school. International Journal of Research and Analytical Reviews, 3(3), $1-8$.

[17] Portal Pejabat Pendidikan Daerah Johor Bahru. (2015). Retrieved from http://ppdjb.edu.my/v3/sekolah2.php

[18] Krejcie, R. V. \& Morgan, D. W. (1970). Determining sample size for research. Educational and Psychological Measurement, 30, $607-610$.

[19] Glynn, S. M., Brickman, P., Armstrong, N. \& Taasoobshirazi, G. (2011). Science motivation questionnaire II: Validation with science majors and nonscience majors. Journal of Research in Science Teaching, 48(10), $1159-1176$.

[20] Maxwell, D. O., Lambeth, D. T., \& Cox, J. T. (2015). Effects of using inquiry-based learning on science achievement for fifth-grade students. Asia-Pacific Forum on Science Learning and Teaching, 16(1), 1-31.

[21] Osborne, J., Simon, S., \& Collins, S. (2003). Attitude towards science: a review of the literature and its implications. International Journal of Science Education, 25(9), 1049-1079.

[22] Schiefele, U. (1991). Interest, learning and motivation. Educational Psychologist, 26(2\&3), 299-323.

[23] Sorić, I. \& Palekčić, M. (2009). The role of students' interests in self-regulated learning: The relationship between students' interests, learning strategies and causal attributions. European Journal of Psychology of Education, 24(4), 545-565.

[24] Aikenhead, G. S. (2006). Science education for everyday life: Evidence-based practice. New York: Teachers College Press.

[25] Obomanu, B. J., \& Adaramola, M. O. (2011). Factors Related to Under Achievement in Science, Technology and Mathematics Education (STME) in Secondary Schools in Rivers State, Nigeria. World Journal of Education, 1(1), 102 - 109.

[26] Miller, R. B. \& Brickman, S. J. (2004). A model of future-orientated motivation and self-regulation. Educational Psychology Review, 16(1), 9-33.

[27] Miller, R. B., DeBacker, T. K., \& Greene, B. A. (1999). Perceived instrumentality and academics: The link to task valuing. Journal of Instructional Psychology, 26, 250 -261.

[28] Harackiewicz, J. M., Tibbetts, Y., Canning, E. \& Hyde, J. S. (2014). Hardenessing values to promote motivation in education. Advances in Motivation and Achievement, 18, 71-105.

[29] Vansteenkiste, M., Simons, J., Lens, W., Soenens, B., Matos, L., \& Lacante, M. (2004). Less Is Sometimes More: Goal Content Matters. Journal of Educational Psychology, 96 (4), 755-764. 